\title{
Article \\ Towards Recreation of Food Commodities Based on Ancient Texts; The Case of Avyrtake
}

\author{
Spiros Paramithiotis ${ }^{1, *(\mathbb{D}}$, Maria K. Syrokou ${ }^{1}$, Anastasia Papadia-Nikolaidou ${ }^{1}$, Georgios Papoutsis ${ }^{2}$ \\ and Eleftherios H. Drosinos ${ }^{1}$ \\ 1 Department of Food Science and Human Nutrition, Agricultural University of Athens, Iera Odos 75, \\ GR-11855 Athens, Greece; syrokoumargia@aua.gr (M.K.S.); \\ stud513022@aua.gr (A.P.-N.); ehd@aua.gr (E.H.D.) \\ 2 Directorate of Secondary Education, Ministry of Education, Research and Religious Affairs, \\ GR-15180 Athens, Greece; papougeo14@gmail.com \\ * Correspondence: sdp@aua.gr
}

\section{check for}

updates

Citation: Paramithiotis, S.;

Syrokou, M.K.;

Papadia-Nikolaidou, A.;

Papoutsis, G.; Drosinos, E.H.

Towards Recreation of Food

Commodities Based on Ancient Texts;

The Case of Avyrtake. Appl. Sci. 2022,

12, 1697. https://doi.org/10.3390/

app12031697

Academic Editors: Maria Luisa

Savo Sardaro and Lorenza Conterno

Received: 27 December 2021

Accepted: 4 February 2022

Published: 7 February 2022

Publisher's Note: MDPI stays neutral with regard to jurisdictional claims in published maps and institutional affiliations.

Copyright: (C) 2022 by the authors. Licensee MDPI, Basel, Switzerland. This article is an open access article distributed under the terms and conditions of the Creative Commons Attribution (CC BY) license (https:// creativecommons.org/licenses/by/ $4.0 /)$.

\begin{abstract}
The aim of the present study was to attempt the recreation of a highly appreciated food commodity of antiquity, called avyrtake, using information derived from ancient texts. The available information included the raw materials, the texture and the taste of the raw materials. On the contrary, the relative proportion of the raw materials as well as the production procedure had to be inferred on the basis of their modern-day use. For that purpose, and based on the above, a mixture of shredded cabbage and leek, salt, pomegranate seeds, raisins, and shredded garlic, as well as ground green cardamon and mustard seeds were pressed into a fermentation jar in order to form a brine and left at $18{ }^{\circ} \mathrm{C}$ for fermentation to take place. The latter was driven by lactic acid bacteria, mostly by Lactiplantibacillus plantarum. The final product had a sour character, which matched the organoleptic description available from the ancient texts, and it received high ranks.
\end{abstract}

Keywords: cabbage; leek; pomegranate seeds; raisins; garlic; green cardamon; mustard seeds; lactic acid fermentation; Lactiplantibacillus plantarum

\section{Introduction}

A wide variety of lactic acid fermented fruits and vegetables are currently available worldwide. For some of them, such as Korean kimchi, written historical texts have been retrieved, revealing important information about their consumption in ancient times and providing a historical connection between the populations residing in certain geographical areas [1]. In Ancient Greece, the lactic acid fermentation of fruits and vegetables was not as widespread as alcoholic fermentation. In fact, it may be characterized as rather unusual, due to the climatic conditions that enabled a stable supply of fresh fruits and vegetables throughout the year and the preferred use of dehydration and smoking for preservation purposes [2]. The production procedure and, in many cases, the exact recipes of an extended diversity of products consumed in ancient Mediterranean basin was revealed by many Greek and Roman authors. The most prominent ancient gastronomical textbooks that provide with a wealth of important information regarding eating habits are Deipnosophistae by Athenaeus and the Apicius manuscript.

However, there was a product that, although highly appreciated, the information retrieved from ancient texts, regarding its production procedure, is rather limited. This product was called 'avyrtake', and the land of Medes, which today includes areas mainly of Iran and Iraq, was mentioned by Theopompus (5th century B.C.) [3] in his work 'Theseus', as well as by Demetrius II (3rd century B.C.) [4], in his comic poem 'Areopagites', as its origin. The production procedure seems to be quite demanding and required proper training, preferably by local craftsmen. Indeed, the main character in 'Areopagites', among his achievements, claimed to have learned the art of avyrtake-making in the court of 
Seleucus I Nicanor, who ruled the eastern part of the empire of Alexander the Great. Unfortunately, there are no written archives describing the exact production procedure. However, the raw materials used, the texture and the taste of the product, have been described. Indeed, according to Theopompus (5th century B.C.) [3], Athenaeus (2nd century A.C.) [5], Photios (9th century A.C.) [6] and Eustathius (12th century A.C.) [7], the raw materials included leafy vegetables, leek, cardamom, garlic, raisins, pomegranate and mustard seeds, which were mixed and ground together. The latter may be used as an indicator of texture, which was further clarified by the word ' $\chi \lambda$ ó $\eta$ ' (phonetically transcribed as kla'wij and translated as 'grass') that Athenaeus used to describe it [5]. This word implies that the product had the form of long, narrow particles, most likely due to the use of leafy vegetables and leeks as the major ingredients that were cut into that shape. The taste of the final product was described as intense and sour. The latter indicates acid fermentation, most likely by lactic acid bacteria, since the addition of any type of acidulant, such as vinegar, was not mentioned, at least by Greek authors of that period.

In the present day, some of the raw materials that are mentioned above are commonly used for the production of lactic acid fermented products. Indeed, leafy vegetables are widely used as a fermentation substrate in European, Asia-Pacific and African countries [8-10] and lactic acid fermentation of leek has also been reported [11,12]. Regarding the remaining raw materials, garlic is very often included in the production of a variety of products, such as kimchi [1], ca muoi [13] and tursu [14], and mustard seeds for the production of hardaliye [15]. The aim of the present study was to recreate this product through a production procedure that is based on the raw materials mentioned in the ancient texts and their use as revealed by worldwide assessment of spontaneously fermented vegetables and to further study the dynamics of the developing microecosystem.

\section{Materials and Methods}

\subsection{Avyrtake Preparation and Sampling}

Three kilograms of shredded cabbage (Brassica oleracea) was mixed with $1.2 \mathrm{~kg}$ of shredded leek (Allium ampeloprasum) and $63 \mathrm{~g}$ table salt, applying gentle pressure. Then, $90 \mathrm{~g}$ of shredded garlic (Allium sativum), $90 \mathrm{~g}$ pomegranate (Punica granatum) seeds, $90 \mathrm{~g}$ raisins, $60 \mathrm{~g}$ ground green cardamon (Elettaria cardamomum) seeds and $60 \mathrm{~g}$ ground mustard (Brassica alba) seeds were added and mixed together. The latter two ingredients were ground through mortar and pestle. The mixture was placed into two $2 \mathrm{~kg}$ containers, applying pressure so that a brine is formed (Figure S1). The brine surface was covered with olive oil, and the mixture was left to ferment at $18{ }^{\circ} \mathrm{C}$ until the fermentation was considered complete, i.e., until both $\mathrm{pH}$ and total titratable acidity (TTA) values, measured in two consecutive samplings, exhibited no statistically significant difference $(p<0.05)$.

Sampling took place at days 1, 3, 7, 15, 22 and 29. The fermenting mixture was gently mixed, then $10 \mathrm{~g}$ of solid particles and $5 \mathrm{~mL}$ of brine were aseptically derived for microbiological and physicochemical analyses, respectively.

\subsection{Microbiological and Physicochemical Analyses}

Microbiological analyses were performed in the solid particle samples at days 1, 3, 7, 15, 22 and 29. Initial and serial dilutions were performed in sterile Ringer solution (LAB M, Lancashire, U.K.). The enumeration of total aerobic mesophilic microorganisms, yeasts/molds, lactic acid bacteria, enterococci, Enterobacteriaceae, pseudomonads, Staphylococcus aureus and Escherichia coli was performed in every sample. In brief, the pour-plating technique using De Mann, Rogosa and Sharpe agar, Violet Red Bile Glycose agar (LAB M) and Chromocult $^{\circledR}$ TBX agar (Merck, Darmstadt, Germany) was applied to enumerate lactic acid bacteria, Enterobacteriaceae and E. coli, respectively, with an enumeration limit of 1 $\log$ CFU/g. The spread-plating technique using Plate Count Agar (LAB M), Rose Bengal Chloramphenicol Agar (LAB M), Baird-Parker selective agar (LAB M), Kanamycin Aesculin Azide Agar (LAB M), and Pseudomonas Agar base supplemented with Cephalothin, Fucidin and Cetrimide (LAB M) was used for total aerobic mesophilic, yeasts/molds, 
St. aureus, enterococci and pseudomonads enumeration, respectively, with an enumeration limit of $2 \log$ CFU/g. Detection of Listeria monocytogenes and Salmonella sp. was performed according to ISO 11290-1:2017 (Part I) and ISO 6579-1, respectively.

$\mathrm{pH}$ value was measured directly in the derived brine sample (WTW, Weilheim, Germany). Acidity was titrated with $0.1 \mathrm{~N} \mathrm{NaOH}$ to final $\mathrm{pH}$ value of 8.5; TTA was expressed in \% lactic acid. Analyses were performed in duplicate.

\subsection{Isolation and Identification of Lactic Acid Bacteria}

Isolation of lactic acid bacteria took place at days 3, 7, 15, 22 and 29. Colonies were selected according to the procedure suggested by Harrigan and McCance [16] and purified by successive subculturing on MRS agar. Catalase reaction and Gram stain were performed for confirmatory reasons. Pure lactic acid bacteria colonies were inoculated into MRS broth and incubated at $30^{\circ} \mathrm{C}$ for $24 \mathrm{~h}$. Then, DNA extraction was performed according to Doulgeraki et al. [17]. Random amplified polymorphic DNA-polymerase chain reaction (RAPD-PCR) was employed for LAB clustering. In brief, RAPD-PCR was performed in $20 \mu \mathrm{L}$ volume containing $0.2 \mathrm{mM}$ dNTPs (Peqlab, Erlangen, Germany), $2.5 \mathrm{mM} \mathrm{MgCl}$, $4 \mu \mathrm{M}$ primer (M13: GAGGGTGGCGGTTCT) and 2 U Taq polymerase (Kapa Biosystems, Boston, MA, U.S.A.). The thermocycling conditions were: initial denaturation at $95{ }^{\circ} \mathrm{C}$ for $2 \mathrm{~min}, 35$ cycles of $95{ }^{\circ} \mathrm{C}$ for $1 \mathrm{~min}, 38^{\circ} \mathrm{C}$ for $1 \mathrm{~min}$ ramp to $72{ }^{\circ} \mathrm{C}$ at $0.6{ }^{\circ} \mathrm{C} \mathrm{s}-1,72{ }^{\circ} \mathrm{C}$ for $2 \mathrm{~min}$ and a final extension step at $72{ }^{\circ} \mathrm{C}$ for $10 \mathrm{~min}$. Separation of the amplicons was performed by electrophoresis in $1.5 \%$ agarose gel in $1.0 \times$ Tris-acetate EDTA (TAE) at $100 \mathrm{~V}$ for $1.5 \mathrm{~h}$, with visualization by ethidium bromide staining and documentation using the GelDoc system (Bio-Rad, Hercules, CA, USA). Clustering of the genotypic profiles was performed using the Dice coefficient and the unweighted pair group method with arithmetic mean (UPGMA) cluster analysis of the Bionumerics software v. 6.1 (Applied Maths NV, Sint-Martens-Latem, Belgium). Depending on the size of each cluster, one to three representative strains were selected and subjected to sequencing of their V1-V3 region of the $16 \mathrm{~S}$ rRNA gene (approximately $700 \mathrm{bp}$ ) according to Doulgeraki et al. [18] for phylogenetic and taxonomic assessment.

In addition, the specific PCR developed by Berthier and Ehrlich [19] for Lactiplantibacillus plantarum identification was also applied. In brief, PCR was performed in $20 \mu \mathrm{L}$ volume containing $0.25 \mathrm{mM}$ dNTPs (Peqlab, Erlangen, Germany), $2.5 \mathrm{mM} \mathrm{MgCl} 2,0.3 \mu \mathrm{M}$ each primer (16: GCTGGATCACCTCCTTTC; Lpl: ATGAGGTATTCAACTTATG) and 2 U Taq polymerase (Kapa Biosystems, Boston, MA, USA). The thermocycling conditions were initial denaturation at $94{ }^{\circ} \mathrm{C}$ for $5 \mathrm{~min}, 30$ cycles of $94{ }^{\circ} \mathrm{C}$ for $1 \mathrm{~min}, 53^{\circ} \mathrm{C}$ for $1 \mathrm{~min}, 72{ }^{\circ} \mathrm{C}$ for $1.5 \mathrm{~min}$ and a final extension step at $72{ }^{\circ} \mathrm{C}$ for $7 \mathrm{~min}$. Gel electrophoresis was performed as previously described; the presence of a $265 \mathrm{bp}$ amplicon was indicative of Lp. plantarum.

\subsection{Sensory Evaluation}

Sensory evaluation was performed according to Skonberg et al. [20] and Zhu et al. [21]. In brief, 25 participants, who liked to consume pickled vegetables, were recruited and were asked to evaluate the product in terms of color, texture, aroma, flavor and overall acceptability ( 1 being extremely dislike to 9 being extremely like) as well as to describe the taste in terms of sourness, bitterness, sweetness, saltiness and umami ( 1 being least intense to 9 being most intense). The product (ca. $50 \mathrm{~g}$ ) was served, chilled, two weeks after the end of fermentation.

\subsection{Statistical Analysis}

One-way analysis of variance (ANOVA) with post-hoc Fisher's least significant difference (LSD) procedure $(p<0.05)$ was performed to assess the differences between the results of the physicochemical and microbiological analyses as well as between the sensorial attributes. The correlation between the sensorial attributes was assessed by the Pearson coefficient. All calculations were performed in Statgraphics Centurion XVII (Statgraphics Technologies, Inc., The Plains, VA, USA). 


\section{Results}

In Table 1, the microbiological and physicochemical changes during spontaneous avyrtake fermentation are shown. The initial $\mathrm{pH}$ and TTA values were 4.98 and $0.11 \%$ LA, respectively. The former decreased to 3.54 , while the latter increased to $1.12 \%$ LA at the end of fermentation. Pseudomonads, yeasts/molds, St. aureus and E. coli populations were below the enumeration limit already from the first day and remained throughout fermentation. The only exception was the $3.23 \log \mathrm{CFU} / \mathrm{g}$ of yeasts/molds enumerated in the 3rd day of fermentation. The absence of L. monocytogenes and Salmonella sp. was observed throughout fermentation. On the contrary, lactic acid bacteria, Enterobacteriaceae and enterococci populations were enumerated from the first day of fermentation. The first increased until the 7th day, reaching $8.68 \log \mathrm{CFU} / \mathrm{g}$, and then decreased to $7.90 \log \mathrm{CFU} / \mathrm{g}$ at the end of fermentation. The Enterobacteriaceae population decreased from $4.94 \mathrm{log}$ $\mathrm{CFU} / \mathrm{g}$ initially to below the enumeration limit on the 22nd day of fermentation. Finally, the enterococci population increased until the 3rd day of fermentation to $6.96 \log \mathrm{CFU} / \mathrm{g}$ and then gradually decreased to $5.24 \log \mathrm{CFU} / \mathrm{g}$ at the end of fermentation.

Table 1. Physicochemical and microbiological changes during spontaneous avyrtake fermentation.

\begin{tabular}{|c|c|c|c|c|c|c|c|}
\hline Day & $\mathrm{pH}$ & TTA $^{1}$ (\%LA) & TAMC $^{2}$ & LAB $^{3}$ & Enterobacteriaceae & Enterococci & Yeasts/Molds \\
\hline 1 & $4.98(0.13)^{\mathrm{a}}$ & $0.11(0.01)^{a}$ & $5.66(0.33)^{a}$ & $5.89(0.27)^{\mathrm{a}}$ & $4.94(0.23)^{\mathrm{a}}$ & $5.05(0.14)^{\mathrm{a}}$ & $<2$ \\
\hline 3 & $4.21(0.01)^{b}$ & $0.27(0.01)^{b}$ & $7.97(0.01)^{b}$ & $8.02(0.16)^{b}$ & $4.02(0.03)^{b}$ & $6.96(0.16)^{b}$ & $3.23(0.33)$ \\
\hline 7 & $4.03(0.02)^{c}$ & $0.42(0.01)^{c}$ & $8.89(0.15)^{c}$ & $8.68(0.14)^{c}$ & $2.95(0.67)^{\mathrm{c}}$ & $6.63(0.89)^{a b}$ & $<2$ \\
\hline 15 & $3.51(0.01)^{d}$ & $0.76(0.01)^{d}$ & $8.79(0.44)^{c}$ & $8.39(0.55)^{b c}$ & $3.92(0.10)^{b}$ & $6.19(0.83)^{\mathrm{a}}$ & $<2$ \\
\hline 22 & $3.50(0.07)^{d}$ & $1.08(0.07)^{e}$ & $8.07(0.10)^{b}$ & $8.15(0.21)^{b}$ & $<1$ & $5.80(0.34)^{\mathrm{a}}$ & $<2$ \\
\hline 29 & $3.54(0.06)^{d}$ & $1.12(0.05)^{\mathrm{e}}$ & $7.77(0.24)^{b}$ & $7.90(0.07)^{b}$ & $<1$ & $5.24(1.07)^{\mathrm{a}}$ & $<2$ \\
\hline
\end{tabular}

${ }^{1}$ Total titratable acidity; ${ }^{2}$ total aerobic mesophilic count; ${ }^{3}$ lactic acid bacteria. Microbial populations are given in $\log (\mathrm{CFU} / \mathrm{g})$. Different superscript letters within a column designate statistically significant differences $(p<0.05)$.

A total of 159 lactic acid bacteria isolates were obtained throughout the fermentation; they were subjected to RAPD-PCR analysis and separated into six clusters (Figure S2). Representative strains from each cluster were subjected to specific PCR and sequencing of their 16S-rRNA gene to obtain their taxonomic affiliation. The majority of the isolates (115) were assigned to Lp. plantarum-group by 16S-rRNA gene sequencing and specifically identified as $L p$. plantarum by specific PCR. The remaining 44 isolates were identified as Levilactobacillus brevis. The latter were grouped in cluster I, while the former in clusters II-VI. In Figure 1, the population dynamics during spontaneous avyrtake fermentation is presented. $L p$. plantarum dominated the fermentation already from the 3rd day. Lv. brevis was detected on the 7th, 15th, 22nd and 29th days of fermentation, forming an accompanying secondary microbiota.

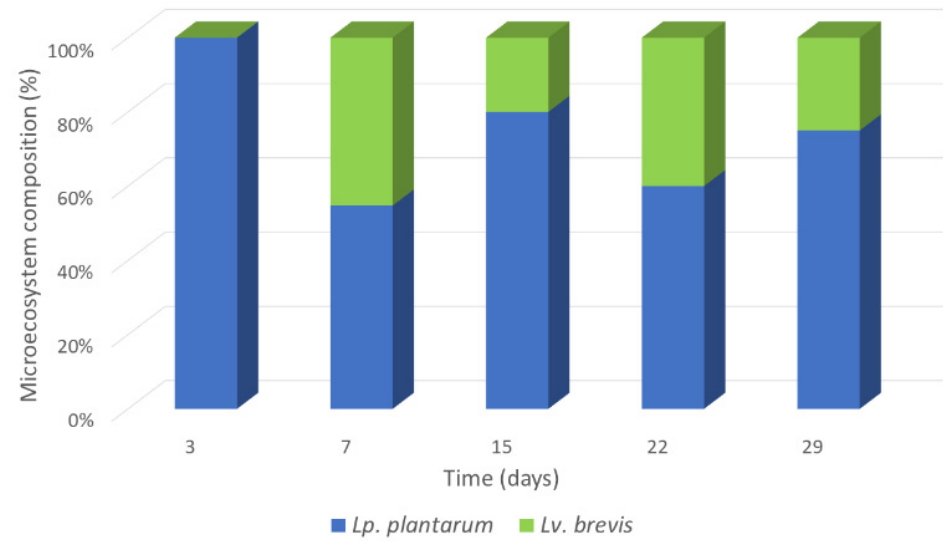

Figure 1. Population dynamics during spontaneous avyrtake fermentation. 
In Table 2, the sensory evaluation of spontaneously fermented avyrtake is presented. The product presented acceptable color, satisfying aroma and flavor, while texture received the lowest score; the highest rank was received by flavor. Overall, the product was characterized as highly acceptable. Regarding the taste description, the product was distinguished by its sourness, whereas bitterness received the lowest score. Sweetness, saltiness and umami tastes received equally moderate ranks. No statistically significant correlation was achieved between overall acceptance with any of the other attributes assessed.

Table 2. Sensory evaluation of spontaneously fermented avyrtake.

\begin{tabular}{ccc}
\hline Attribute & Score \\
\hline & product evaluation & \\
\hline Aroma & $7.0(0.93)^{\mathrm{ab}}$ \\
Flavor & $7.6(0.91)^{\mathrm{c}}$ \\
Color & $7.4(0.81)^{\mathrm{bc}}$ \\
Texture & $6.6(0.87)^{\mathrm{a}}$ \\
Overall acceptability & $7.6(0.96)^{\mathrm{c}}$ \\
\hline Sourness & taste description & \\
\hline Bitterness & $5.9(0.88)^{\mathrm{a}}$ \\
Sweetness & $2.3(0.97)^{\mathrm{c}}$ \\
Saltiness & $4.8(1.04)^{\mathrm{b}}$ \\
Umami & $4.8(0.94)^{\mathrm{b}}$ \\
\hline
\end{tabular}

The average values are presented. Standard deviation is given in parenthesis. Different superscript letters designate statistically significant differences between the scores of the attributes referring to product evaluation and taste description $(p<0.05)$.

\section{Discussion}

In the present study, the recreation of a highly appreciated product, based on information that is available in ancient texts, was attempted. This information included the type of the raw materials, the texture and the organoleptic characteristics of the final product. The information that was not available and had to be inferred referred to the quantity of the raw materials and the production procedure.

The raw materials included leafy vegetables, leek, cardamom, garlic, raisins, pomegranate and mustard seeds; all of them are still used for the production of a variety of products. This list of ingredients was derived from ancient texts and may not be exhaustive; however, it is indicative of a product consisting of several ingredients, some of which may largely contribute to the aroma and taste formation of the final product. Their relative proportion to the recipe was inferred by their modern-day use. A wide range of leafy vegetables are currently used as the basic substrate for lactic acid fermentation. In Asia, the most commonly used belong to the Brassica genus, namely, mustard leaves, cauliflower leaves and cabbage leaves [9]. The type of leaves employed, direct the initial processing steps that are necessary to soften their texture and improve their edibility and palatability. Indeed, mustard leaves are very often subjected to sun wilting or soaking in boiled water. In the present study, in order to simplify the procedure, only cabbage leaves were used, which do not require such processing. However, the existence of such or other processing steps may not be excluded. The use of leek as a basic ingredient $[11,12,22]$ as well as an optional ingredient, in order to contribute to the overall taste $[23,24]$ has been reported. The special reference to the leek content of avyrtake, made by Theopompus (5th century B.C.) in his work 'Theseus' [3], led to the conclusion that it could be among the basic ingredients. However, due to the intense aroma and flavor, its use at a proportion of 1:2.5 (leek to cabbage), was decided. Garlic is very often included in the recipe of mixtures subjected to spontaneous lactic acid fermentation, such as kimchi [24-26] and Sichuan pao cai [27], but always in a proportion of less than 3\% of the total ingredient weight. Garlic is particularly rich in sulfur compounds [28] and it has been reported to enhance LAB growth during the early 
stages of kimchi fermentation [26]. The functional potential of pomegranate juice, due to its high polyphenolic content, has been adequately highlighted [29]. In addition, its suitability as a substrate for lactic acid fermentation [30] as well as being a probiotic carrier [31], has been exhibited. From a technological perspective, pomegranate seeds and raisins enrich the vegetable mixture with carbohydrates [32,33], assisting water extraction from the plant tissues and providing the microorganisms with fermentable carbon sources. The use of cardamom and mustard seeds has also been reported [1,34,35]. Apart from the effect on the organoleptic quality of the final product, both assist in brine formation through the physical damage of the plant tissue during mixing. As far as sodium chloride is concerned, its addition was not mentioned in any ancient text. However, its function as a selective agent favoring growth of LAB led to its use at relevant amount $(1.3 \% w / w)$.

The production procedure was directed by the description of the texture of the final product, as well as the selection of cabbage as the major ingredient. The texture was described as grass-like, occurring after mixing and grinding together the raw materials. However, the extend of grating and grinding was not revealed. Coarse grating would lead to a texture similar to modern day sauerkraut; on the other hand, fine grating would lead to a paste-like product that is rarely reported for fermented vegetables and is most common for soybean preparations. Therefore, coarse grating was selected. When leafy vegetables are used, grating aims for the formation of brine. This is facilitated by mixing with small particles, such as cardamom and mustard seeds as well as carbohydrate-rich ingredients, such as raisins and pomegranate seeds. In modern days, brine formation is also facilitated by $\mathrm{NaCl}$ addition.

Lactic acid bacteria dominated the microecosystem of avyrtake already from the first day of fermentation. The concomitant reduction of the $\mathrm{pH}$ value and the development of acidity resulted in the decrease in the Enterobacteriaceae population. On the contrary, enterococci retained high population levels due to their tolerance to acidic environments [36]. Lactiplantibacillus plantarum dominated the lactic acid microbiota from the third day of fermentation, with $L v$. brevis forming the secondary biota. The dominance of $L p$. plantarum may be attributed to its large metabolic capacity and tolerance to acidic conditions [37]. Indeed, its participation and, in many cases, dominance of the LAB microecosystem was reported in a wide range of spontaneously fermented vegetables [38-45]. Similarly, $L v$. brevis is very often reported as background microbiota, mainly due to its ability to tolerate stressful conditions [39].

The sensorial evaluation of the final product revealed its sour character, which matched the organoleptic description available from the ancient texts. Overall, the product was characterized as highly acceptable, despite the combination of several ingredients with intense flavors and the further enrichment by lactic acid fermentation. Texture received the lowest score, which can be attributed to the $\mathrm{NaCl}$ addition. Indeed, $\mathrm{NaCl}$ has been extensively reported to affect the texture of sauerkraut in a concentration-dependent way [46,47]. More accurately, Wolkers-Rooijackers et al. [46] reported that sauerkraut produced with $15 \mathrm{~g} / \mathrm{kg}$ of $\mathrm{NaCl}$ had better texture, in terms of firmness, compared to that produced with a lower $\mathrm{NaCl}$ content $(9 \mathrm{~g} / \mathrm{kg})$. In addition, Johanningsmeier et al. [48] reported a significant loss of firmness as the concentration of $\mathrm{NaCl}$ decreased from 20 to $5 \mathrm{~g} / \mathrm{kg}$. Despite the textural defects encountered in sauerkraut produced with only $10 \mathrm{~g} / \mathrm{kg} \mathrm{NaCl}$, the application of Leuconostoc mesenteroides as a starter culture contributed to the manufacture of a final product with a perceived texture similar to that obtained with higher $\mathrm{NaCl}$ concentrations. This, probably, was also the case of the present study. Although the $\mathrm{NaCl}$ content in avyrtake was not low enough $(13.5 \mathrm{~g} / \mathrm{kg})$ to cause a potential loss of firmness with concomitant softening of the cabbage or leek, the use of an appropriate starter culture could compensate for the aforementioned textural imperfections.

\section{Conclusions}

The recreation of a historical and highly appreciated food commodity, on the basis of descriptions retrieved from ancient texts, was attempted. Through the assessment of 
worldwide traditions regarding spontaneously fermented vegetables, missing information was inferred, and a highly acceptable product was developed.

Supplementary Materials: The following supporting information can be downloaded at: https:/ /www. mdpi.com/article/10.3390/app12031697/s1, Figure S1: Preparation of avyrtake. A: The ingredients are mixed. B: The mixture is placed into the containers and brine is formed. C: Avyrtake is ready for consumption. Figure S2: Cluster analysis of PCR-RAPD patterns of bacterial isolates. Distance is indicated by the mean correlation coefficient $[\mathrm{r}(\%)]$ and clustering was performed by UPGMA analysis. The representative strains selected for $16 \mathrm{~S}$ rRNA gene sequencing are in red.

Author Contributions: Conceptualization, S.P. and G.P.; methodology, S.P. and A.P.-N.; data curation, S.P., A.P.-N. and M.K.S.; writing—original draft preparation, S.P., M.K.S. and G.P.; writing—review and editing, S.P., M.K.S., A.P.-N., G.P. and E.H.D. All authors have read and agreed to the published version of the manuscript.

Funding: This research has received no external funding.

Institutional Review Board Statement: Not applicable.

Informed Consent Statement: Not applicable.

Data Availability Statement: The data presented in this study are available in the manuscript.

Conflicts of Interest: The authors declare no conflict of interest.

\section{References}

1. Patra, J.K.; Das, G.; Paramithiotis, S.; Shin, H.S. Kimchi and other widely consumed traditional fermented foods of Korea: A review. Front. Microbiol. 2016, 7, 1493. [CrossRef] [PubMed]

2. Paramithiotis, S.; Papoutsis, G.; Drosinos, E.H. Lactic acid fermentation of fruits and vegetables: An overview. In Lactic Acid Fermentation of Fruits and Vegetables; Paramithiotis, S., Ed.; CRC Press: Boca Raton, FL, USA, 2017; pp. 1-18.

3. Meineke, A. Fragmenta Comicorum Graecorum Collegit et Sisposuit Augustus Meineke; Voluminis II Fragmenta Poetarum Comoediae Antiquae Continentis; G. Reimeri: Berlin, Germany, 1840; p. 798.

4. Bothe, F.H. Poetarum Comicorum Graecorum Fragmenta Post Augustum Meineke Recognovit et Latine Transtulit Fredericus Henricus Bothe; Ambrosio Firmin Didot: Paris, France, 1855; p. 700.

5. Athenaeus. The Deipnosophists with an English Translation by Charles Burton Gulick; Harvard University Press: Cambridge, MA, USA, 1927.

6. Photios. Lexicon. Available online: https://dcthree.github.io/photios/ (accessed on 11 January 2022).

7. Eustathius. Commentarii ad Homeri Odysseam II. Available online: http://www.poesialatina.it/_ns/Greek/testi/Eustathius/ Commentarii_ad_Homeri_Odysseam02.html (accessed on 11 January 2022).

8. Wiander, B. Sauerkraut Fermentation. In Lactic Acid Fermentation of Fruits and Vegetables; Paramithiotis, S., Ed.; CRC Press: Boca Raton, FL, USA, 2017; pp. 65-81.

9. Swain, M.R.; Ananadharaj, M. Regional fermented vegetables and fruits in Asia-Pacific. In Lactic Acid Fermentation of Fruits and Vegetables; Paramithiotis, S., Ed.; CRC Press: Boca Raton, FL, USA, 2017; pp. 181-203.

10. Oguntoyinbo, F.A.; Franz, C.M.A.P. Regional fermented fruits and vegetables in Africa. In Lactic Acid Fermentation of Fruits and Vegetables; Paramithiotis, S., Ed.; CRC Press: Boca Raton, FL, USA, 2017; pp. 237-266.

11. Wouters, D.; Bernaert, N.; Conjaerts, W.; Van Droogenbroeck, B.; De Loose, M.; De Vuyst, L. Species diversity, community dynamics, and metabolite kinetics of spontaneous leek fermentations. Food Microbiol. 2013, 33, 185-196. [CrossRef] [PubMed]

12. Yang, J.; Ji, Y.; Park, H.; Lee, J.; Park, S.; Yeo, S.; Shin, H.; Holzapfel, W.H. Selection of functional lactic acid bacteria as starter cultures for the fermentation of Korean leek (Allium tuberosum Rottler ex Sprengel.). Int. J Food Microbiol. 2014, 17, 164-171. [CrossRef] [PubMed]

13. Nguyen, D.T.L.; Van Hoorde, K.; Cnockaert, M.; De Brandt, E.; Aerts, M.; Binh Thanh, L.; Vandamme, P. A description of the lactic acid bacteria microbiota associated with the production of traditional fermented vegetables in Vietnam. Int. J. Food Microbiol. 2013, 163, 19-27. [CrossRef] [PubMed]

14. Kabak, B.; Dobson, A.D.W. An introduction to the traditional fermented foods and beverages of Turkey. Crit. Rev. Food Sci. Nutr. 2011, 51, 248-260. [CrossRef]

15. Coskun, F.; Arici, M. Effect of the use of different mustard seeds and grape varieties on some properties of Hardaliye. Acad. Food J. 2011, 9, 6-11.

16. Harrigan, W.F.; McCance, M.E. Laboratory Methods in Food and Dairy Microbiology; Academic Press: London, UK, 1976; pp. 47-49.

17. Doulgeraki, A.I.; Paramithiotis, S.; Nychas, G.J.E. Characterization of the Enterobacteriaceae community that developed during storage of minced beef under aerobic or modified atmosphere packaging conditions. Int. J. Food Microbiol. 2011, 145, 77-83. [CrossRef] 
18. Doulgeraki, A.I.; Paramithiotis, S.; Kagkli, D.M.; Nychas, G.J.E. Lactic acid bacteria population dynamics during minced beef storage under aerobic or modified atmosphere packaging conditions. Food Microbiol. 2010, 27, 1028-1034. [CrossRef]

19. Berthier, F.; Ehrlich, S.D. Rapid species identification within two groups of closely related lactobacilli using PCR primers that target the 16S/23S rRNA spacer region. FEMS Microbiol. Lett. 2006, 161, 97-106. [CrossRef]

20. Skonberg, D.I.; Fader, S.; Perkins, L.B.; Perry, J.J. Lactic acid fermentation in the development of a seaweed sauerkraut-style product: Microbiological, physicochemical, and sensory evaluation. J. Food Sci. 2021, 86, 334-342. [CrossRef]

21. Zhu, W.; Luan, H.; Bu, Y.; Li, X.; Li, J.; Zhang, Y. Identification, taste characterization and molecular docking study of novel umami peptides from the Chinese anchovy sauce. J. Sci. Food Agric. 2021, 101, 3140-3155. [CrossRef]

22. Patra, J.K.; Das, G.; Paramithiotis, S. Kimchi: A well-known Korean traditional fermented food. In Lactic Acid Fermentation of Fruits and Vegetables; Paramithiotis, S., Ed.; CRC Press: Boca Raton, FL, USA, 2017; pp. 83-106.

23. Cho, J.H.; Lee, D.Y.; Yang, C.N.; Jeon, J.I.; Kim, J.H.; Han, H.U. Microbial population dynamics of kimchi, a fermented cabbage product. FEMS Microbiol. Lett. 2006, 257, 262-267. [CrossRef] [PubMed]

24. Jeong, S.H.; Jung, J.Y.; Lee, S.H.; Jin, H.M.; Jeon, C.O. Microbial succession and metabolite changes during fermentation of dongchimi, traditional Korean watery kimchi. Int. J. Food Microbiol. 2013, 164, 46-53. [CrossRef]

25. Lee, J.-S.; Heo, G.-Y.; Lee, J.W.; Oh, Y.-J.; Park, J.A.; Park, Y.-H.; Pyun, Y.-R.; Ahn, J.S. Analysis of kimchi microflora using denaturing gradient gel electrophoresis. Int. J. Food Microbiol. 2005, 102, 143-150. [CrossRef]

26. Cho, H.-K.; Park, S.-H.; Jung, C.-S.; Jo, J.-S. Effect of the garlic on the fermentation and quality of kimchi. J. Korean Soc. Food Cult. 2001, 16, 470-477.

27. Xiao, M.; Peng, Z.; Hardie, W.J.; Huang, T.; Liu, Z.; Zhang, Y.; Xie, M.; Xiong, T. Exploring the typical flavours formation by combined with metatranscriptomics and metabolomics during Chinese Sichuan paocai fermentation. LWT Food Sci. Technol. 2022, 153, 112474. [CrossRef]

28. Batiha, G.E.-S.; Beshbishy, A.M.; Wasef, L.G.; Elewa, Y.H.A.; Al-Sagan, A.A.; El-Hack, M.E.A.; Taha, A.E.; Abd-Elhakim, Y.M.; Devkota, H.P. Chemical constituents and pharmacological activities of garlic (Allium sativum L.): A review. Nutrients 2020, $12,872$. [CrossRef] [PubMed]

29. Fahmy, H.; Hegazi, N.; El-Shamy, S.; Farag, M.A. Pomegranate juice as a functional food: A comprehensive review of its polyphenols, therapeutic merits, and recent patents. Food Funct. 2020, 11, 5768. [CrossRef]

30. Di Cagno, R.; Filannino, P.; Gobbetti, M. Lactic acid fermentation drives the optimal volatile flavor-aroma profile of pomegranate juice. Int. J. Food Microbiol. 2017, 248, 56-62. [CrossRef]

31. Mustafa, S.M.; Chua, L.S.; El-Enshasy, H.A. Effects of agitation speed and kinetic studies on probiotication of pomegranate juice with Lactobacillus casei. Molecules 2019, 24, 2357. [CrossRef]

32. El-Nemr, S.E.; Ismail, I.A.; Raga, M. Chemical composition of juice and seeds of pomegranate fruit. Nahrung 1990, 34, 601-606. [CrossRef]

33. Olmo-Cunillera, A.; Escobar-Avello, D.; Pérez, A.J.; Marhuenda-Muñoz, M.; Lamuela-Raventós, R.; Vallverdú-Queralt, A. Is Eating Raisins Healthy? Nutrients 2020, 12, 54. [CrossRef] [PubMed]

34. Erten, H.B.; Agirman, C.P.B.; Gunduz, A.B. Ghorbal Regional fermented vegetables and fruits in Europe. In Lactic Acid Fermentation of Fruits and Vegetables; Paramithiotis, S., Ed.; CRC Press: Boca Raton, FL, USA, 2017; pp. 205-235.

35. Tamang, J.P. Himalayan Fermented Foods: Microbiology, Nutrition and Ethnic Values; CRC Press: Boca Raton, FL, USA, 2010.

36. Fisher, K.; Phillips, C. The ecology, epidemiology and virulence of Enterococcus. Microbiology 2009, 155, 1749-1757. [CrossRef]

37. Daeschel, M.A.; Andersson, R.E.; Fleming, H.P. Microbial ecology of fermenting plant materials. FEMS Microbiol. Rev. 1987, 46, 357-367. [CrossRef]

38. Hong, Y.; Yang, H.-S.; Chang, H.-C.; Kim, H.-Y. Comparison of bacterial community changes in fermenting kimchi at two different temperatures using a denaturing gradient gel electrophoresis analysis. J. Microbiol. Biotechnol. 2013, 23, 76-84. [CrossRef] [PubMed]

39. Pardali, E.; Paramithiotis, S.; Papadelli, M.; Mataragas, M.; Drosinos, E.H. Lactic acid bacteria population dynamics during spontaneous fermentation of radish (Raphanus sativus L.) roots in brine. World J. Microbiol. Biotechnol. 2017, 33, 110. [CrossRef]

40. Singh, A.K.; Ramesh, A. Succession of dominant and antagonistic lactic acid bacteria in fermented cucumber: Insights from a PCR-based approach. Food Microbiol. 2008, 25, 278-287. [CrossRef]

41. Barrangou, R.; Yoon, S.S.; Breidt, F., Jr.; Fleming, H.P.; Klaenhammer, T.R. Identification and characterization of Leuconostoc fallax strains isolated from an industrial sauerkraut fermentation. Appl. Environ. Microbiol. 2002, 68, 2877-2884. [CrossRef]

42. Sesena, S.; Palop, M.L. An ecological study of lactic acid bacteria from Almagro eggplant fermentation brines. J. Appl. Microbiol. 2007, 103, 1553-1561. [CrossRef]

43. Pulido, R.P.; Ben Omar, N.; Abriouel, H.; Lopez, R.L.; Martınez Canamero, M.; Galvez, A. Microbiological study of lactic acid fermentation of caper berries by molecular and culture-dependent methods. Appl. Environ. Microbiol. 2005, 71, 7872-7879. [CrossRef]

44. Paramithiotis, S.; Hondrodimou, O.L.; Drosinos, E.H. Development of the microbial community during spontaneous cauliflower fermentation. Food Res. Int. 2010, 43, 1098-1103. [CrossRef]

45. Wouters, D.; Grosu-Tudor, S.; Zamfir, M.; De Vuyst, L. Bacterial community dynamics, lactic acid bacteria species diversity and metabolite kinetics of traditional Romanian vegetable fermentations. J. Sci. Food Agric. 2013, 93, 749-760. [CrossRef] [PubMed]

46. Wolkers-Rooijackers, J.C.M.; Thomas, S.M.; Nout, M.J.R. Effects of sodium reduction scenarios on fermentation and quality of sauerkraut. LWT Food Sci. Technol. 2013, 54, 383-388. [CrossRef] 
47. Yang, X.; Hu, W.; Xiu, Z.; Jiang, A.; Sarengaowa, G.; Ji, Y.; Guan, Y.; Feng, K. Effect of salt concentration on microbial com-munities, physicochemical properties and metabolite profile during spontaneous fermentation of Chinese northeast sauerkraut. J. Appl. Microbiol. 2020, 129, 1458-1471. [CrossRef] [PubMed]

48. Johanningsmeier, S.; Mcfeeters, R.F.; Fleming, H.P.; Thompson, R.L. Effects of Leuconostoc mesenteroides starter culture on fermentation of cabbage with reduced salt concentrations. Food Microbiol. Saf. 2007, 72, M166-M172. [CrossRef] [PubMed] 